\title{
光重合型コンポジットレジンの破壊エネルギ計測*
}

\section{Measurement of Fracture Energy in a Light Cure Composite Resin} \\ Kazuo ARAKAWA*3, Masaru KATO and Toshio MADA \\ *3 Research Institute for Applied Mechanics, Kyushu University, \\ 6-1 Kasuga-koen, Kasuga-shi, Fukuoka, 816-8580 Japan
}

新川和夫苂, 加藤 大 $^{* 2}$, 馬田俊 雄*1

\begin{abstract}
Brittle fracture behavior of a light cure composite resin was studied using a high-speed extensometer. The single-edge-notched tensile specimens were fractured with a special loading jig so that it could split and fly away after the fracture. The load and displacement diagram, i.e. the external work applied to the specimen was partitioned into three parts: the elastic energy left in the fractured specimen, the nonelastic energy due to viscoplastic deformation and the fracture energy for creating new surfaces. These energies were then determined and correlated with the fracture load. Energy release rates were also evaluated, and the results were discussed.
\end{abstract}

Key Words: High Polymer Material, Light Cure Composite Resin, Brittle Fracture, Fracture Energy, Elastic Energy, Nonelastic Energy, Fracture Load, External Work, HighSpeed Extensometer.

\section{1. 緒 言}

歯科用光重合型コンポジットレジンは，審美性や操 作性に優れるため, 近年, 臨床で広く使用される修復材 料となっている. しかしながら従来の金属性修復材料と 比べて, 而擵耗性や破壞強度などの機械特性が十分では なく,より信頼性の高いコンポジットレジンの開発が望 まれている. また一方では, 力学的信頼性を調べるため に, コンポジットレジンの破壊䩒性が計測されている. 通常の計測法では，試験片に作用する荷重が計測され， き裂寸法などの条件から破壊䩚生が決定されている.し かしながら光照射による重合のため，作製できる試験片 寸法には制限があり，破壊䩚性計測法で推奨されている 試験片形状を満足させることは容易ではない. そのため, 試験片形状や実験法として, 種々のものが提唱されてい $ろ^{(1)(4)}$. 一方，コンポジットレジンも他の高分子材料と 同様に粘弾性効果 ${ }^{(5)}$ が生じること，また脆性的なため， き裂が高速度で進展し, 材料の変形に伴う慣性力や運動 エネルギが無視できず, 動的効果(6)(26)が発生する可能性 がある.しかしながら粘性や動的効果を定量的に評価す ることは技術的に容易ではなく,コンポジットレジンの 破壊挙動に及ぼすこれらの効果は考察されていないの

* 原稿受付 2008 年 10 月 20 日.

*1 正員, 九州大学応用力学研究所(隶 816-8580 春日市春日公 園 6-1).

*2 九州大学大学院総合理工学府.

E-mail : k.arakaw@ riam.kyushu-u.ac.jp
が現状である.

筆者らは，これまでに高分子材料の脆性破壇におけ る粘性や動的効果を評価することを目的として,引張り 破壊計測装置の開発を進めてきたた (27)(28)。この装置の特 徽は, 光ファイバを用いた変位計により,き裂近傍の静 的およひ動的変位が精度良く計測できることこれによ り粘弾性変形を含む残留変位が定量的に評価できるこ とである.また静的な負荷条件下においては，破断後の 試験片の運動を拘束しないため負荷方向への飛しょう が可能となり，試験片に蓄積された弾性エネルギ，すな わち動的効果を評価できることである.この装置を用い て,これまでに種々の高分子材料の脆性破壊を計測した。 そして, 粘性や動的効果を定量的に評価できることこ れらの効果が破壊举動に大きな影響を及ぼすことを示 してきた(27),(28).

本研究では，提唱した計測手法のコンポジットレジ ンへの適応性を検討した. しかしながら上述のように, 光照射による重合のため，作製できる試験片寸法には制 限があり，引張り負荷を作用させることは容易ではない， このため, 本研究ではコンポジットレジンを 2 枚の PMMA 帯板間に充填させた片側ノッチ付き引張り試験 片を作製した。試験片に作用する荷重と変位より外力仕 事, 破断直後の残留変位より非弾性エネルギを求めた. また破断後の飛しょう高さより,試験片内部に蓄積され た弾性エネルギを決定した.これらの值よりコンポジッ 
トレジンの破壊エネルギを求め, 外力仕事との比を求め た.さらに破面の面積を用いて, エネルギ解放率を求め, 破断荷重之の対応関係を検討した. また, PMMA 単体 の試験片との比較検討を行った.

\section{2. 試験片およひ実験方法}

\section{2-1 材料およひ試験片形状 光重合型コンポジッ} トレジンとして,クラレメディカル(株)社製のクリアフ イルAP-Xを使用した。この材料は, 歯科臨床で一般的 に使用されている充填材である. 上述のように, 光重合 により硬化させるため，作製できる試験片寸法には制限 がある、そのため，本研究では，図1（a)に示すような 試験片を作製した。この試験片は，2枚のPMMAの带 板間にコンポジットレジンを充填したものであり,引張 り試験が容易となる。ここで PMMAは，コンポジット レジンと比較的に材料定数が近いこと, また両者の接着 性が良好であることから採用した。

試験片の作製法を以下に示寸. (1) 板厚 $3 \mathrm{~mm}$, 幅 $20 \mathrm{~mm}$, 長さ90mm のPMMA (Sumipex E) 帯板を2枚用意寸る. (2) 帯板の端面にボンディング剂（クリアフィルトライ エスボンド: クラレメディカル(株)製）を塗布し，光照 射器（株モリタ JETLITE 3000）を用いて硬化させた。 (3) 2 枚の帯板を透明な平板（板厚 $5 \mathrm{~mm}$ のPMMA）上に 載せ，直線になるように型枠で挟み込さ. (4) 帯板の端 面間を $10 \mathrm{~mm} に$ 設定し，その間にコンポジットレジンを 充填した. (5) コンポジットレジンを一様に重合させ, 試験片の反りを避けるため, 下面上上面を交互に8回 (5 秒 4 回, その後, 10 秒 4 回) 照射した. また型枠から分 離後, コンポジットレジンの左右端を10秒照射した. (6) コンポジットレジンとPMMAの面が同一になるように 研磨した. (7) その後, コンポジットレジンを十分に重 合させるため，室温・大気中で24 時間放置した。

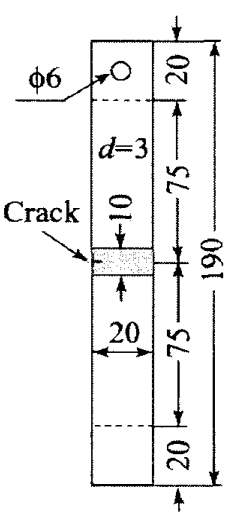

(a) Composite resin

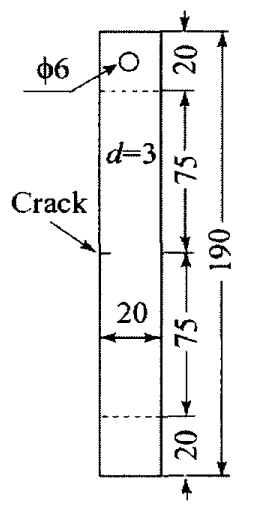

(b) PMMA
Fig. 1 Specimen geometries.
試験片の片側中央部に切欠きを導入し，その先端部を カミソリで鋭くした.ただし試験片の破断荷重および外 力仕事を変化させるため, 異なる長さ2〜7mmの切久き を導入した. さらに試験片の上端には直径 $6 \mathrm{~mm}$ の穴を あけ，ピン負荷用とした. また比較検討のため, 図 1 (b) のような PMMA 試験片を作製した. なお以下では, 便宜上，図 1 (a)をコンポジット試験片と呼ぶ.

$2 \cdot 2$ 実験方法 図2に静的引張り試験法の概略を 示す. 試験片の下部は固定し, 上部を鋼製のグリップとピ ンを用いることにより引張り負荷を加えた. 引張り速度は, $1 \mathrm{~mm} / \mathrm{min}$ とし, 室温下で実験を行った. な出負荷装置と して, インストロン形引張試験機を用いた. 負荷ジグは鋼 製の丸棒4本で構成されている (図 3 参照)。このため試 験片上部は破断後に負荷方向一の飛しょうが可能とな る. 試験片の飛しょう高さは, 丸棒ジグ間に挿入した薄 い紙パイプ(約0.3g)を用いて計測した.この紙パイプは破 断した試験片部(約30g)とともに飛しょうし, 最大高さで停 止するように設定されている. 最大高さを計測することによ り, 試験片に蓄積された弾性エネルギを求めた.ただし紙 パイプの質量とジグ間との摩擦は無視できる程度の小さ いものと仮定した. また試験片に比べてジグの岡性は十 分高いため,ジグに蓄積されるエネルギが無視できるもの とした. 上述のように, 本実験ではピン負荷を採用した. このため, 圾験片の破断時に曲げ変形が生じ, 飛しょう 高さに影響を及ぼす可能性がある. しかしながら脆性材 料であるPMMAやコンポジットレジンでは, き裂が高速 度で進展し, 試験片は瞬時に破断するため, 飛しよう高さ に及ぼす曲げの影響は小さいものと仮定した。

变位計測法の概略を図 2 に示す. ピン負荷部の変位 $2 \delta$ は, 試験機のクロスヘッドの移動量より求めた。一方, き裂 近傍の変位 $\delta^{\prime}$ の計測には高速度変位計を利用した(27),(28). この変位計では, 光ファイバを試験片に貼り付け，その移

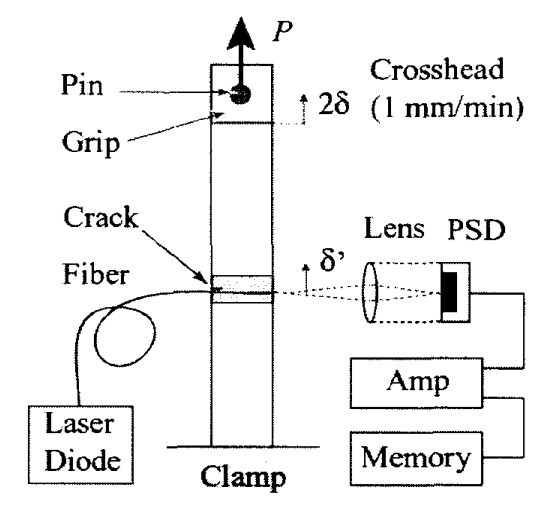

Fig. 2 Experimental setup. 


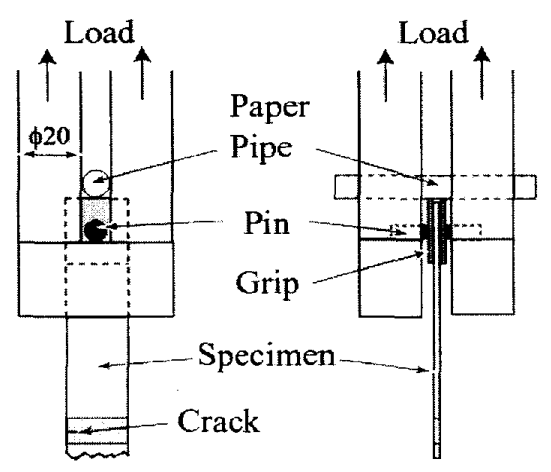

Fig. 3 Loading jigs for static test.

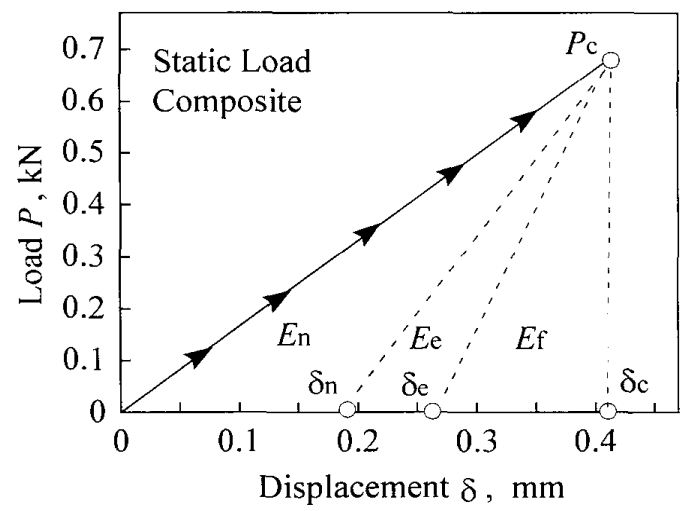

Fig. 4 Load $P$ versus displacement $\delta$.

動量を PSD (Position Sensing Detector) センサザ計測する. センサカらの出力波形はアンプで増幅した後, デジタルメ モリで記録した.このセンサは約 $100 \mathrm{kHz}$ の応答速度を有 しており，静的および動的変位計測に使用可能である.な お高速き裂進展による影響を避けるため，光フアイバを切 欠きか放 $2 \mathrm{~mm}$ 離れた下部に貼り付けた.ただしこの影響 は，クロスヘッド移動量半分 $\delta$ とき裂近傍変位 $\delta$ の差 $\Delta \delta\left(=\delta-\delta^{\prime}\right)$ を用いて補正することができる.

\section{3. 実験結果}

図 4 に試験片に作用寸る荷重 $P$ と試験片中央の変位 $\delta$

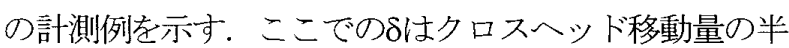
分を表す.また破断時の荷重を $P_{\mathrm{c}}$, 変位を $\delta_{\mathrm{c}}$ で表示した。 $P は \delta$ 共に増加し，試験片が破断すると急激に低下し た.さらにP- $\delta$ 関係は直線的に変化しており, 見かけ上, 非線形効果は顕著でないことが示されている。

図 5 に試験片破断前後における切欠き近傍での変位 $\delta^{\prime}$ の変化挙動を示す。ここで明らかなことは， $\delta_{\mathrm{c}}^{\prime} て ゙$ 急 激に低下し，その後は残留変位 $\delta_{n}^{\prime}$ を中心に減衰を伴い

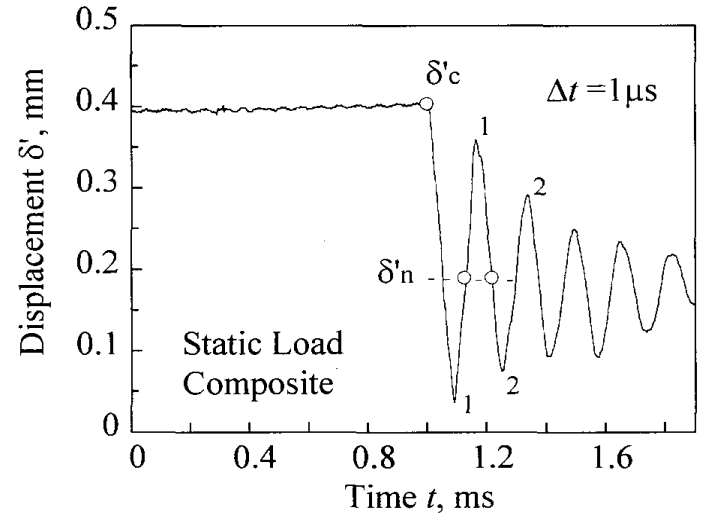

Fig. 5 Displacement $\delta^{\prime}$ versus time $t$.

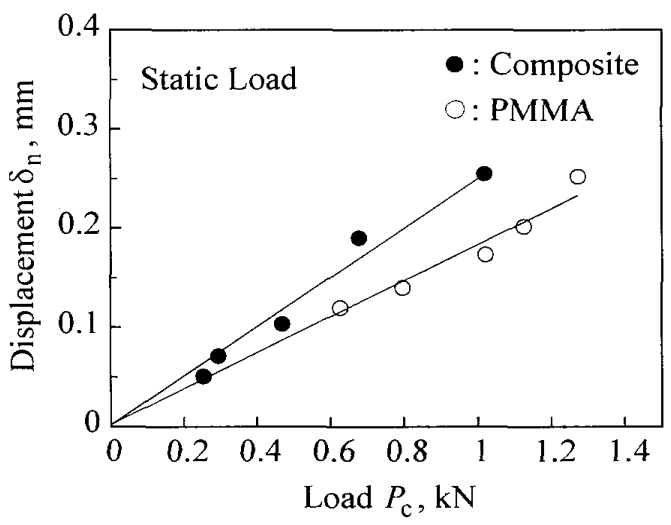

Fig. 6 Residual displacement $\delta_{\mathrm{n}}$ versus fracture load $P_{\mathrm{c}}$.

ながら振動したことである.すなわちこの結果は，静 的負荷の場合には，粘弾性や塑性変形による非弾性変 位が生じることを意味している. なおう $\delta_{\mathrm{n}}^{\prime}$ 值は以下のよ うに求めた. (1) データのサンプリングを $1 \mu \mathrm{s}$ 間隔で行 った (図 5 参照) . (2) 破断直後の振動の中心值を初期 波形の 2 周期で求めた. (3) その中心值の平均を $\delta_{\mathrm{n}}^{\prime}$ とし て採用した。 なお得られた $\delta_{\mathrm{n}}^{\prime}$ を試験片中央での值 $\delta_{\mathrm{n}} に$ 補正した結果を図 6 に示す。ここでは異なる初期切欠 き長さを有するコンポジットおよび PMMAの各 5 本 の試験片から得られた結果を破断荷重 $P_{\mathrm{c}}$ の関数として 表示した.ただし，コンポジット試験片では，負荷後 に界面はく離やき裂が存在したものはデータから除外 した．両試験片において， $P_{\mathrm{c}}$ ともに列が増加した. この結果は，破断荷重が大きくなると残留変位，すな わち非弾性エネルギが増加することを意味している。 またコンポジット試験片の $\delta_{\mathrm{n}}$ が PMMAより大きな值 となっており，両試験片での残留変位に差が生じるこ とが示されている。 


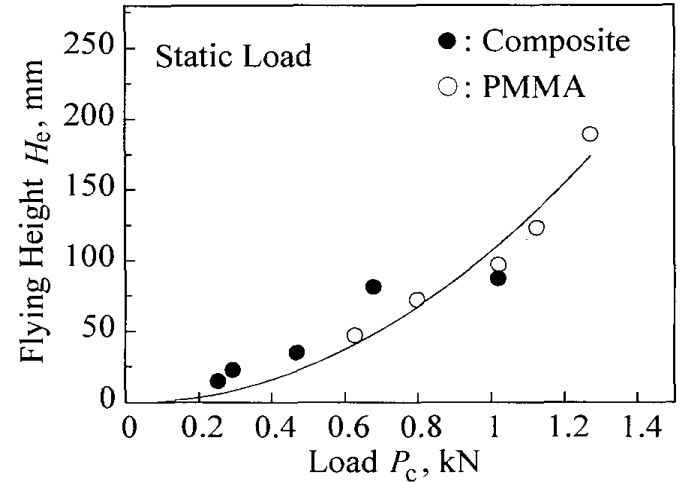

Fig. 7 Flying height $H_{\mathrm{e}}$ versus fracture load $P_{\mathrm{c}}$.

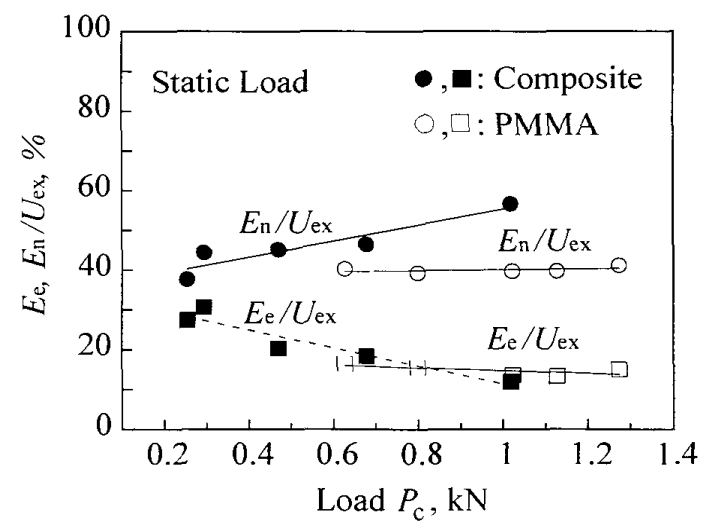

Fig. 8 Energy ratios $E_{\mathrm{e}} / U_{\mathrm{ex}}$ and $E_{\mathrm{n}} / U_{\mathrm{ex}}$ versus fracture load $P_{\mathrm{c}}$.

図３の負荷ジグは，破断後に試験片の運動を拘束し ないように設計されている. そのため破断した試験片上 部の最大飛しよう高さ $H_{\mathrm{e}}$ を計測することが可能となる。 そ の計測結果を図 7 に示す。ここでは $H_{\mathrm{e}}$ 孛破断荷重 $P_{\mathrm{c}}$ の 関数として表示した。コンポジット試験片の計測值に はばらつきがあるものの， $H_{\mathrm{e}}$ はP $P_{\mathrm{c}}$ ともに増加した。 すなわちこの結果は，PMMAと同様に破断荷重が大き くなると，試験片内部に蓄積される弾性エネルギが増 加寸ること，また両試験片での弾性エネルギ值に大き な差が生じないことを示唆している.

\section{4. 破壊エネルギ解析}

4-1 破壊エネルギの定義＼cjkstart試験片に作用する外 力仕事 $U_{\mathrm{ex}}$ は，P $P \delta$ 関係を直線で近似寸ると, 次式 で与えられる (図 4 参照).

$$
U_{\mathrm{ex}}=P_{\mathrm{c}} \delta_{\mathrm{c}} / 2
$$

ここで $P_{\mathrm{c}}$ と $\delta_{\mathrm{c}}$ は破断時の荷重と変位を表す.

本研究では, 破壞変形のプロセスが，き裂の進展，試 験片の破断，それに伴う弾性変形の解放と試験片の飛し よう, 最後に非弾性変形の残留という順序で生じるもの

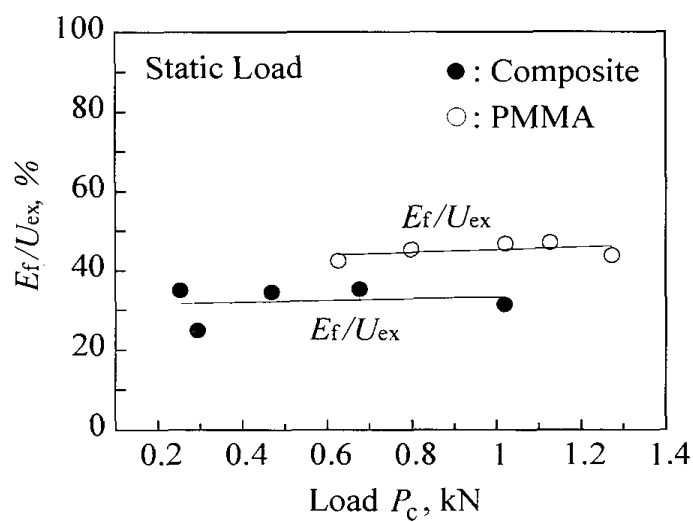

Fig. 9 Energy ratio $E_{\mathrm{f}} / U_{\mathrm{ex}}$ versus fracture load $P_{\mathrm{c}}$.

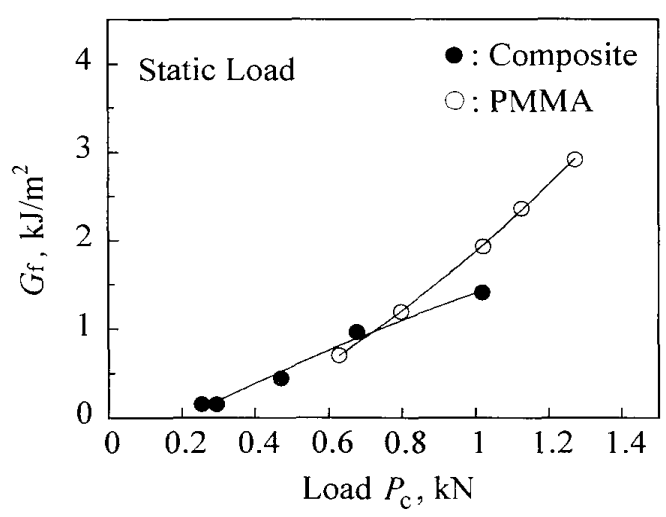

Fig. 10 Energy release rate $G_{f}$ versus fracture load $P_{\mathrm{c}}$.

と考える．そして試験片の破断直前には，U $U_{\mathrm{ex}}$ が図4に 示されるように, 以下の3つのエネルギ成分に分離でき るものと仮定する

$$
U_{\mathrm{ex}}=E_{\mathrm{f}}+E_{\mathrm{e}}+E_{\mathrm{n}}
$$

本解析では試験片半分を対象としているため, 式(2) の $E_{\mathrm{f}}$ は全破壞エネルギの半分を表わす.すなわち $E_{\mathrm{f}}$ は， 破面の形成に必要な表面エネルギ，き裂から放出され る音響エネルギ，き裂周辺の温度上昇に寄与する熱工 ネルギなど非可逆的な総エネルギの半分に対态する.

一方, $E_{\mathrm{e}}$ は試験片に蓄積される弾性的なひずみエネル ギ， $E_{\mathrm{n}}$ は粘性や塑性ひずみなど破断後も試験片に残留 する非弹性的な総工ネルギの半分に相当する.

本研究では，弾性エネル $E_{\mathrm{e}}$, 非弾性エネルギ $E_{\mathrm{n}}$ を評 価するため，以下のことを仮定した（1) $E_{\mathrm{e}}$ は試験片が 破断すると全て運動エネルギに変換する.(2) 動的破壊 で生じる除荷過程では粘弾性効果が無視できる ${ }^{(11),(12)}$. すなわち $P_{\mathrm{c}}$ から破断直後の全変位 $\delta_{\mathrm{e}}$ や残留変位 $\delta_{\mathrm{n}} \sim の$ 変化が弾性的と亓る（図 4 参照）。その結果，次式が 成立する. 


$$
\frac{E_{\mathrm{e}}}{U_{\mathrm{ex}}}=\frac{\left(\delta_{\mathrm{e}}-\delta_{\mathrm{n}}\right)}{\delta_{\mathrm{c}}}, \quad \frac{E_{\mathrm{n}}}{U_{\mathrm{ex}}}=\frac{\delta_{\mathrm{n}}}{\delta_{\mathrm{c}}}
$$

4-2 非弾性エネルギ $E_{\mathrm{n}}$ 非弾性エネルギ $E_{\mathrm{n}}$ 值は,

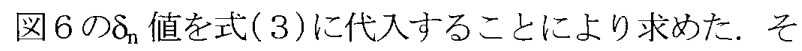
の結果を図 8 に示す.ここでは $E_{\mathrm{n}}$ と外力仕事の比 $E_{\mathrm{n}} / U_{\mathrm{ex}}$ を破断荷重 $P_{\mathrm{c}}$ の関数として表示した. コンポジット試験 片の $E_{\mathrm{n}} / U_{\mathrm{ex}}$ 值として， $P_{\mathrm{c}}$ が小さいところでは約 $38 \%$, 比 較的高いところで約 $57 \%$ 年得られており， $P_{\mathrm{c}}$ とともに 増加した. 一方, PMMAの $E_{\mathrm{n}} / U_{\mathrm{ex}}$ 值は， $P_{\mathrm{c}}$ の広い範囲で 約 $40 \%$ の一定值を示した.

$4 \cdot 3$ 弾性エネルギ $E_{\mathrm{e}}$ 破断した試験片上部の最 大飛しよう高さ $H_{\mathrm{e}}$ を計測した(図 7 参照)，そして，試験片 に蓄積された弾性エネルギ $E_{\mathrm{e}}$ を次式で求めた.

$$
E_{\mathrm{e}}=m g H_{\mathrm{e}}
$$

ここで，mは負荷用グリップとピンを含めた試験片上部 の質量, $g$ は重力加速度を表す。

図8に式 $(4)$ より求めた $E_{\mathrm{e}}$ 值走示す。ここでは $E_{\mathrm{e}}$ と 外力仕事の比 $E_{\mathrm{e}} / U_{\mathrm{ex}}$ 表示した. コンポジット試験片 の $E_{\mathrm{e}} / U_{\mathrm{ex}}$ 值として，P花が小さいところでは約 $27 \%$ ，比較 的高いところでは約 $12 \%$ 年られており， $E_{\mathrm{n}} / U_{\mathrm{ex}}$ 值とは 逆の傾向が示されている。 一方, PMMA $の E_{\mathrm{e}} / U_{\mathrm{ex}}$ 值は 約14\%の一定值を示した.

$4 \cdot 4$ 破壊エネルギ $E_{\mathrm{f}}$ 得られた外力仕事 $U_{\mathrm{ex}}$, 非 弾性エネルギ $E_{\mathrm{n}}$, 弾性エネルギ $E_{\mathrm{e}}$ 䒚式 (2)に代入するこ とにより $E_{\mathrm{f}}$ 值を求めた。 その結果を図 9 に示す。ここ では $E_{\mathrm{f}}$ と外力仕事の比 $E_{\mathrm{f}} / U_{\mathrm{ex}}$ を破断荷重 $P_{\mathrm{c}}$ の関数として 表示した.コンポジット試験片の $E_{\mathrm{f}} / U_{\mathrm{ex}}$ 值にはバラツキ が存在したものの, 約 $32 \% か ゙$ 得られた。一方, PMMA $の E_{\mathrm{f}} / U_{\mathrm{ex}}$ 值は約 $45 \%$ を示した。すなわち両試験片におい て約13\%の差が存在した。

4 -5 エネルギ解放率 $G_{\mathrm{f}}$ エネルギ解放率は，一般 的に外力仕事 $U_{\mathrm{ex}}$ を破面の面積 $A_{\mathrm{s}}$ で割ることにより求 められている.しかしながら破壊変形の大きい高分子 材料の場合には, 破面形成に直接的に寄与しない弹性 エネルギ $E_{\mathrm{e}}$ と非弾性エネルギ $E_{\mathrm{n}}$ が比較的に大きくな る. そのため, $U_{\mathrm{ex}} / A_{\mathrm{s}}$ でエネルギ解放率を求めると過 大に評価されることになる(図 8参照). 本研究では, 破面形成に寄与する破壞エネルギ $E_{\mathrm{f}}$ を式 $(2)$ で求める ことにより，エネルギ解放率 $G_{\mathrm{f}}$ 莸次式で評価した。

$$
G_{\mathrm{f}}=E_{\mathrm{f}} / A_{\mathrm{s}}
$$

図10に式 5$)$ から導かれた $G_{\mathrm{f}}$ 值を示寸。両試験片に おいて， $G_{\mathrm{f}}$ は一定值でなく， $P_{\mathrm{c}}$ とともに増加した。この $G_{\mathrm{f}}$ と $P_{\mathrm{c}}$ の関係は，脆性高分子材料における動的応力桩
大係数とき裂速度の関係 ${ }^{(20)}$ と定性的に一致する.すなわ ち図100結果は, 各試験片におけるき裂速度が同一では なく, $P_{\mathrm{c}}$ の増加に伴い, き裂速度が大きくなっているこ とを示唆している. またコンポジット試験片における $G_{\mathrm{f}}$ 值の増加公配がPMMAより小さくなる傾向が得られ ている.これを考察するため，両試験片における破面観 察老行った，その結果， $G_{\mathrm{f}}$ 值の増加傾向と破面形態が ほほ類似すること，すなわち $P_{\mathrm{c}}$ の増加に伴い，PMMA では破面が明確に粗くなること、コンポジットレジンで は破面粗さの増加が顕著でないことが観察されている. この結果は, 脆性高分子材料の破面粗さとき裂速度や動 的応力桩大係数の関係 ${ }^{(20)}$ と定性的に一致する. したがっ て図10の結果は, 本研究で提案する試験片形状と計測法 を用いることにより，コンポジットレジンのエネルギ解 放率が定量的に評価できることを示唆している.

\section{5. 結言}

開発した静的引張り試験装置を用いてコンポジット レジンの破壊実験を行なった。試験片に作用する荷重と 変位より外力仕事 $U_{\mathrm{ex}}$, 破断直後の残留変位上り非弾性 エネルギE $E_{\mathrm{n}}$ 求めた。また弾性エネルギ $E_{\mathrm{e}}$ 老試験片の破 断後の飛しょう高さより決定した．破壊エネルギ $E_{\mathrm{f}}$ は $U_{\mathrm{ex}}, E_{\mathrm{n}}, E_{\mathrm{e}}$ より求め, エネルギ比 $E_{\mathrm{n}} / U_{\mathrm{ex}}, E_{\mathrm{e}} / U_{\mathrm{ex}}, E_{\mathrm{f}} / U_{\mathrm{ex}}$ を評価した，さらに破面の面積 $A_{\mathrm{s}}$ を用いて，エネルギ解 放率を $G_{\mathrm{f}}=E_{\mathrm{f}} / A_{\mathrm{s}}$ で求め, 破断荷重 $P_{\mathrm{c}}$ との対応関係を調心゙ た.またPMMA試験片と比較検討した。そして以下の 結果を得た。

(1) コンポジット試験片の $E_{n} / U_{\mathrm{ex}}$ 值は $P_{\mathrm{c}}$ が小さいとこ ろでは約 $38 \%$ ，比較的高いところで約 $57 \%$ を示した。

PMMAではP $P_{\mathrm{c}}$ の広い範囲で約 $40 \%$ の一定值を示した.

(2) コンポジット試験片の $E_{\mathrm{e}} / U_{\mathrm{ex}}$ 值は， $P_{\mathrm{c}}$ が小さいと ころでは約 $27 \%$ ，比較的高いところで約 $12 \%$ 示した。

一方，PMMAでは約14\%の一定值を示した.

(3) コンポジット試験片の $E_{\mathrm{f}} / U_{\mathrm{ex}}$ 值は約 $32 \%$, PMMAで梳約45\%の一定值を示した。

（4）コンポジット試験片の $G_{\mathrm{f}}$ 值は $P_{\mathrm{c}}$ とともに増加し た. しかしその増加勾配は，PMMA より小さくなる傾 向がみられた。

本研究を行うに当たり，クラレメディカル(株)より コンポジットレジン等の実験材料を提供して頂いた。 また，同社歯科材料開発部の山口里志氏，高畑裕祐氏 よりコンポジットレジンの使用方法についての助言を 頂いた，また本研究においては，文部科学省教育研究 特別経費研究推進（大学間連携）生体バイオマテリア ル高機能インターフェイス科学推進事業から研究費の 一部補助を頂いた，記して謝意を表す。 


\section{文}

1) Kovarik, R.E., Ergle, J.W. and Fairhurst, C.W.: Dental Materials, Vol. 7 (1991) pp. 166-169.

2) Higo, Y., Damri, D., Nunomura, S., Kumada, K., Sawa N., Hanaoka, K., Teranaka, T. and Iwamoto, T. Bio-Medical Materials and Engineering, Vol. 1 (1991) pp. 223-231.

3) Indrani, D.J., Cook, W.D., Televantos, F., Tyas, M.J. and Harcourt, K.: Dental Materials, Vol. 11 (1995) pp.201-207.

4) Knobloch, L.A., Kerby, R.E., Seghi, R., Berlin, J.S., Clelland, N.: The Journal of Prosthetic Dentistry, Vol. 88, No. 3 (2002) pp. 307-313.

5) Williams, J.G.: Fracture Mechanics of Polymers, Ellis Horwood Limited, (1984).

6) Kobayashi, A.S.: Handbook on Experimental Mechanics, Prentice-Hall, Inc., New Jersey (1987).

7) Ravi-Chandar, K.: Physical Aspects of Fracture, Bouchaud, E. et al. editors, Kluwer Academic Publisher, Netherlands, (2001) pp. 323-342.

8) Kobayashi, T. and Dally, J.W.: Fast Fracture and Crack Arrest, Hahn, GT. and Kanninen, M.F., editors, ASTM STP, Vol. 627 (1977) pp. 257-273.

9) Dally, J.W. and Shukla, A.: Eng. Fract. Mech., Vol. 13 (1980) pp. 807-817.

10) Shukla, A. and Nigam, H.: Eng. Fract. Mech., Vol. 25 (1986) pp. 91-102.

11) Kobayashi, A.S., Ramulu, M., Dadkhah, M.S., Yang, K.-H., and Kang, B.S.J.: Int. J. Fract., Vol. 30 (1986) pp. 275-285.

12) Dally, J.W., Agarwal, R.K. and Sanford, R.J.: Exp. Mech., Vol. 30 (1990) pp. 177-183.

13) Theocaris, P.S. and Papadopoulos, G.A.: Eng. Fract. Mech.,
Vol. 13 (1980) pp. 683-698.

14) Kalthoff, J.F.: Workshop on Dynamic Fracture, Knauss, W.G editor, California Institute of Technology, Pasadena (1983) pp. 11-35.

15) Knauss, W.G and Ravi-Chandar, K.: Int. J. Fract., Vol. 27 (1985) pp. 127-143.

16) Takahashi, K. and Arakawa, K.: Exp. Mech., Vol. 27 (1987) pp. 195-200.

17) Katsamanis, F.G and Delides, C.G: J. Phys. D: Appl. Phys., Vol. 21 (1988) pp. 79-86.

18) Suzuki, S., Homma, H. and Kusaka, R.: J. Mech. Phys. Solids, Vol. 36 (1988) pp. 63l-653.

19) Nishioka, T., Murakami, T., Uchiyama, H., Sakakura, K. and Kittaka, H.: Eng. Fract. Mech., Vol. 39 (1991) pp. 757-767.

20) Arakawa, K. and Takahashi, K.: Int. J. Fract., Vol. 48 (1991) pp. 103-114.

21) Arakawa, K. and Takahashi, K.: Int. J. Fract., Vol. 48 (1991) pp. 245-259.

22) Arakawa, K., Nagoh, D. and Takahashi, K.: Int. J. Fract., Vol. 83 (1997) pp. 305-313.

23) Arakawa, K., Nagoh, D. and Takahashi, K.: Int. J. Fract., Vol. 96 (1999) pp. 345-360.

24) Arakawa, K., Mada, T. and Takahashi, K.: Int. J. Fract., Vol. 105 (2000) pp. 311-320.

25) Arakawa, K. and Mada, T.: Exp. Mech., Vol. 46 (2006) pp. 347-353.

26) Arakawa, K., and Mada, T.: Exp. Mech., Vol. 47 (2007) pp. 609-615.

27) Arakawa, K., Mada, T., Park, S.D. and Todo, M.: Polym. Test, Vol. 25 (2006) pp. 628-634.

28) Arakawa, K. and Mada, T.: Exp. Mech., Vol. 47 (2007) pp. 211-216. 